\title{
CXCR4 Peptide Antagonist LY2510924
}

National Cancer Institute

\section{Source}

National Cancer Institute. CXCR4 Peptide Antagonist LY2510924. NCI Thesaurus. Code C106253.

An inhibitor of CXC chemokine receptor 4 (CXCR4), with potential antineoplastic activity. Upon subcutaneous administration, CXCR4 inhibitor LY2510924 binds to the chemokine receptor CXCR4, thereby preventing CXCR4 binding to its lig and, stromal derived factor-1 (SDF-1), and subsequent receptor activation. This may result in decreased tumor cell proliferation and migration. CXCR4, a chemokine receptor belonging to the G proteincoupled receptor (GPCR) gene family, plays an important role in chemotaxis and angiogenesis and is upregulated in several tumor cell types. 